\title{
Sustainable development of regional enterprises based on the neural network profit forecasting model
}

\author{
Nikolai Ivanovich Lomakin \\ Volgograd State Technical University, \\ Economics and Management Faculty \\ Volgograd, Russia \\ te19033176642@yahoo,com
}

\author{
Ekaterina Evgenievna Kharlamova \\ Volgograd State Technical University \\ Economics and Management Faculty \\ Volgograd, Russia \\ sikaterina@mail.ru
}

\author{
Alena Aleksandrovna Polyanskaya \\ Volgograd State Technical University, \\ Economics and Management Faculty \\ Volgograd, Russia \\ helenderbet@mail.ru
}

\begin{abstract}
The article focuses on solving the problem of sustainable development of regions based on the application of artificial intelligence (AI). In the condition of transition to digital economy, the use of the innovation vector is of special significance, e.g. the sustainable development of regions based on the application of big data processing for the purpose of achieving profitable operation of enterprises. Although forecasting corporate profit in the situation of market uncertainty is of great importance, research shows that this area has not been studied sufficiently in scientific literature. A hypothesis has been proposed and validated that it is possible to develop a Rosneft profit forecast with a margin of error of no more than $5 \%$ by using the Perceptron neural network. The developed neural network used is a two-layer perceptron with one hidden layer intended for Rosneft's next year profit forecast. The input layer of the neural network structure includes a number of parameters, such as the American S\&P500 Index, USD rate, BRENT oil price, Rosneft share price - Pros, Gazprom share price - Pgasp, and Rosneft profit - PROFITros. The output layer of the model has only one parameter - Rosneft forecast profit PROFITros(prog).
\end{abstract}

Keywords - artificial intelligence, sustainable development, system element, profit forecast, perceptron, digital economy

\section{INTRODUCTION}

Sustainable development is currently understood to be a type of development which ensures that an organization evolves successfully at present and does not hinder its and its stakeholders' opportunities for future development. Sustainable growth can also be defined as the ability of an organization to maintain its competitive edge in the short, medium and long terms, which, in turn, presupposes both the permanent adaptation of the organization to changes in the environment and ensuring the company's development path in accordance with the trends in the technological development of the industry and economy as a whole.

Addressing the issue of sustainable development of regions based on the application of artificial intelligence is of great importance in the current conditions of digital economy formation against the backdrop of growing market uncertainty and aggravation of all risks.

The significance of this paper lies in the fact that the formation of the innovation vector, i.e. sustainable development of regions based on the application of AI big data processing results plays an important role in securing corporate profitability, which underpins the high practical value of the work.

It is known that the problem of dynamic and sustainable regional development is complex and versatile. Some aspects of sustainable regional development from the perspective of using the financial management potential of a flagship university have been considered by S.P. Sazonov et al [1]. According to E.E. Kharlamova and A.A. Plolyanskaya, the competitive advantages of a regional university can be regarded as drivers ensuring the regional development strategy [2]. The prospect for the application of fuzzy-algorithms and artificial intelligence systems in the risk management of the Common Economic Area (CEA) have been discussed by N.I. Lomakin and E.V. Loginova [3]. V.E. Ekova, O.N. Maksimova and N.I. Lomakin have suggested using the systemic approach to perfect the system of instruments used in sustainable regional development management [4].

The financial area is one of the most important aspects of sustainable regional development. However, it is necessary to 
conduct further research into the main parameter, i.e. the uncertainty factor and financial risk evaluation. In our opinion, Russian researches have made the most substantial progress in this area. For instance, V.A. Vasilyev, A.F. Letchikov and V.E. Lyalin have suggested using real options as a tool to evaluate and hedge corporate risks in the real sector of economy [5].

A number of foreign authors have suggested a comprehensive range of financial mathematical tools which are purposed to be used in risk evaluation and mitigation, including quantile hedging, hedging with minimum deficit risk and quadratic optimal hedging [6].

The application of neural network optimization mechanisms for the 'Green City' budget to ensure sustainable regional development, in particular in Volzhsky City, has been reflected in works by V.A. Kabanov and L.N. Medvedeva [7]. The issues of applying smart modeling to evaluate the investment potential of regions based on quantization have bee studied by A.F. Moskovtsev, A.F. Kopylov, I.A. Samorodova and S.P. Sazonov [8]. K.S. Dontsova and Yu.A. Chebotareva have designed a neural network model for planning urban budget incomes [9].

Since changes in the financial performance of a company affect its share price, let us consider a share price line diagram for oil and gas companies, including Rosneft.

The analysis of share price fluctuations of companies operating the hydrocarbon market from 2008 to 2017 allows us to conclude that only Rosneft has been able to retain the upward trend in the share prices, which was proper to all of them until 2016.

The financial performance of companies is largely dependent on externalities, which, therefore, should be included in the neural network mathematical model.

\section{ROSNEFT'S PROFIT FORECAST NEURAL NETWORK MODEL}

\section{A. AI model formation}

A sample company, Rosneft, was selected as a system element to perform its profit forecasting using the neural network. It was hypothesized that using the artificial intelligence system it could be possible to forecast Rosneft's profit for the next years with a margin of error within 5\%. A non-linear mathematical model was formed on the basis of big data processing results, which was capable of generating a profit forecast value for the company for the next forecasting period of one year. Though Rosneft's profit demonstrated a positive trend in 2007-2014 with a dip in 2013, it has then been declining.

Let us use the capabilities offered by Deductor software developed by BaseGroup to form an artificial intelligence system. The perceptron neural network model is then generated to forecast Rosneft's profit for the next one-year timeframe. The input layer of the neural network structure includes the following parameters: the American S\&P500 Index, USD rate, BRENT oil price, Rosneft share price - Pros, Gazprom share price - Pgasp, and Rosneft profit PROFITros. The output layer of the model has only one parameter - Rosneft forecast profit PROFITros(prog). The relevant input data for the model are given below (Table 1).

TABLE I. INPUT DATA FOR THE NEURAL NETWORK

\begin{tabular}{|c|c|c|c|c|c|c|c|}
\hline \multirow[b]{2}{*}{ Year } & \multicolumn{7}{|c|}{ Parameters } \\
\hline & $\begin{array}{c}S \& P \\
500\end{array}$ & $\begin{array}{c}U S \\
D\end{array}$ & $\begin{array}{c}B r \\
\text { ent }\end{array}$ & Pros & $\begin{array}{r}P \\
\text { gasp }\end{array}$ & Profit ros & $\begin{array}{c}\text { Profit ros } \\
\text { (prognos } \\
\text { ) }\end{array}$ \\
\hline 2016 & 2236 & $\begin{array}{l}61 . \\
27\end{array}$ & $\begin{array}{l}56 . \\
82 \\
\end{array}$ & 402.8 & 154.55 & $\begin{array}{c}9923621 \\
4\end{array}$ & \\
\hline 2015 & 2036 & $\begin{array}{l}72 . \\
64\end{array}$ & $\begin{array}{l}37 . \\
28\end{array}$ & 253.25 & 136.09 & $\begin{array}{c}2394132 \\
55\end{array}$ & $\begin{array}{c}9923621 \\
4\end{array}$ \\
\hline 2014 & $\begin{array}{l}1782 \\
3\end{array}$ & $\begin{array}{l}50 . \\
95\end{array}$ & $\begin{array}{l}57 . \\
33\end{array}$ & 195.8 & 130.31 & $\begin{array}{c}5013242 \\
90\end{array}$ & $\begin{array}{c}2394132 \\
55\end{array}$ \\
\hline 2013 & $\begin{array}{l}1657 \\
6\end{array}$ & $\begin{array}{l}42 . \\
34\end{array}$ & $\begin{array}{c}10 \\
6.4 \\
9\end{array}$ & 251.6 & 138.75 & $\begin{array}{c}1362787 \\
84\end{array}$ & $\begin{array}{c}5013242 \\
90\end{array}$ \\
\hline 2012 & $\begin{array}{l}1310 \\
4\end{array}$ & $\begin{array}{l}39 . \\
93\end{array}$ & $\begin{array}{l}11 \\
4.3 \\
\end{array}$ & 270.01 & 143.7 & $\begin{array}{c}3025006 \\
30\end{array}$ & $\begin{array}{c}1362787 \\
84\end{array}$ \\
\hline 2011 & $\begin{array}{l}1221 \\
7\end{array}$ & $\begin{array}{l}40 . \\
88\end{array}$ & $\begin{array}{c}10 \\
9.8 \\
7\end{array}$ & 270.01 & 143.7 & $\begin{array}{c}3025006 \\
30\end{array}$ & $\begin{array}{c}1362787 \\
84\end{array}$ \\
\hline 2010 & $\begin{array}{l}1157 \\
7\end{array}$ & $\begin{array}{l}40 . \\
26\end{array}$ & $\begin{array}{c}99 . \\
9\end{array}$ & 218.85 & 193.5 & $\begin{array}{c}1919155 \\
83\end{array}$ & $\begin{array}{c}2368194 \\
74\end{array}$ \\
\hline 2009 & $\begin{array}{l}1042 \\
8\end{array}$ & $\begin{array}{l}44 . \\
14\end{array}$ & $\begin{array}{l}78 . \\
57\end{array}$ & 233.81 & 183.09 & $\begin{array}{c}2081797 \\
75\end{array}$ & $\begin{array}{c}1919155 \\
83\end{array}$ \\
\hline 2008 & 8776 & $\begin{array}{l}36 . \\
42\end{array}$ & $\begin{array}{l}44 . \\
78\end{array}$ & 110.9 & 108 & $\begin{array}{c}1413131 \\
62\end{array}$ & $\begin{array}{c}2081797 \\
75\end{array}$ \\
\hline 2007 & $\begin{array}{l}1326 \\
4\end{array}$ & $\begin{array}{l}35 . \\
02\end{array}$ & $\begin{array}{l}93 . \\
25\end{array}$ & 231.7 & 342.88 & $\begin{array}{c}1620216 \\
70\end{array}$ & $\begin{array}{c}1413131 \\
62\end{array}$ \\
\hline
\end{tabular}

Source: Author's development

In our case, the current year actual values turn into the previous year forecast values, as the actual values column shifts one timeframe (year) down.

The back propagation teaching method was applied in the suggested neural network model. The input data array is divided by the program into the teaching sample (95\%) and test sample (5\%). The obtained AI system structure is reflected in the perceptron neural network graph (Fig. 2).

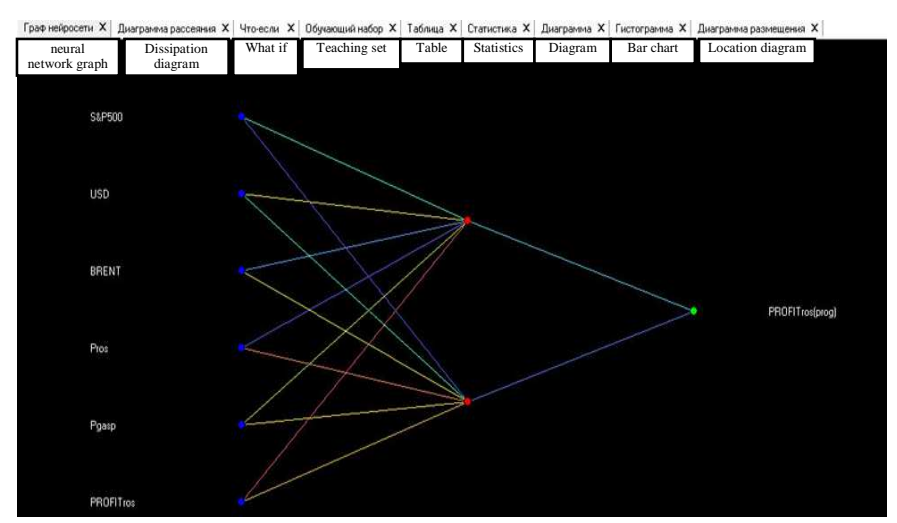

Fig. 1. Neural network graph Source: Author's development 
To obtain Rosneft's estimated net profit forecast values using the neural network model, we will use actual current values for the share prices and other input parameters (Fig. 3).

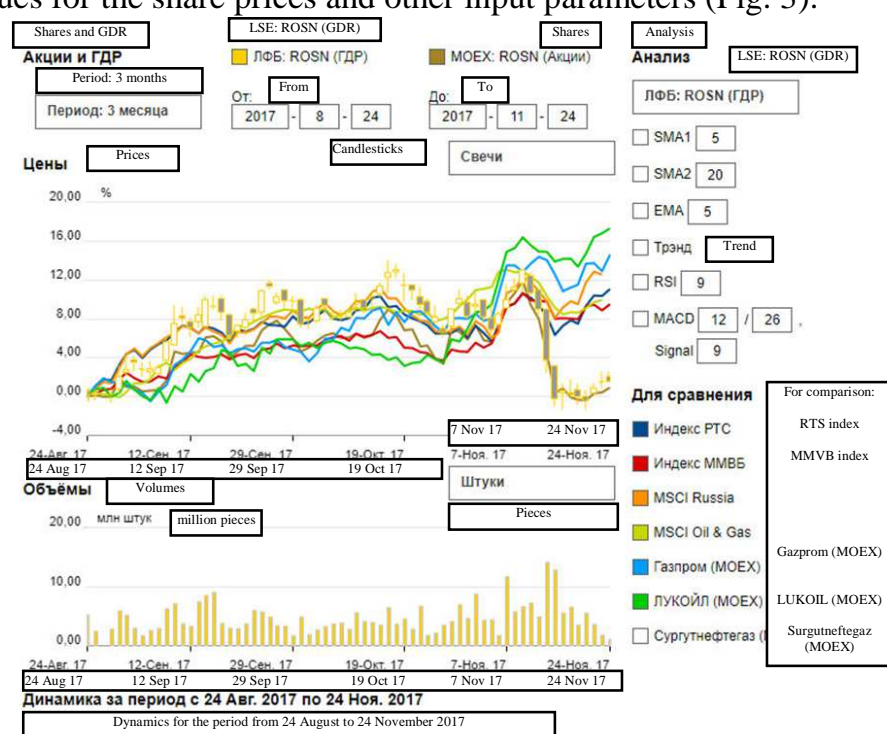

Fig. 2. Rosneft's share price fall in December compared to share prices of other oil and gas companies and stock market indicators in 2017

Source: Author's development

Visualization of obtained data is important. It is possible to include certain factors in the process of 3D diagram generation. In the process of visualization of the obtained data, some correlations between factors can be established. For example, it is absolutely clear that, as the dollar rate and Brent oil price factorial attributes increase, Rosneft's net profit rises accordingly (Fig. 3).

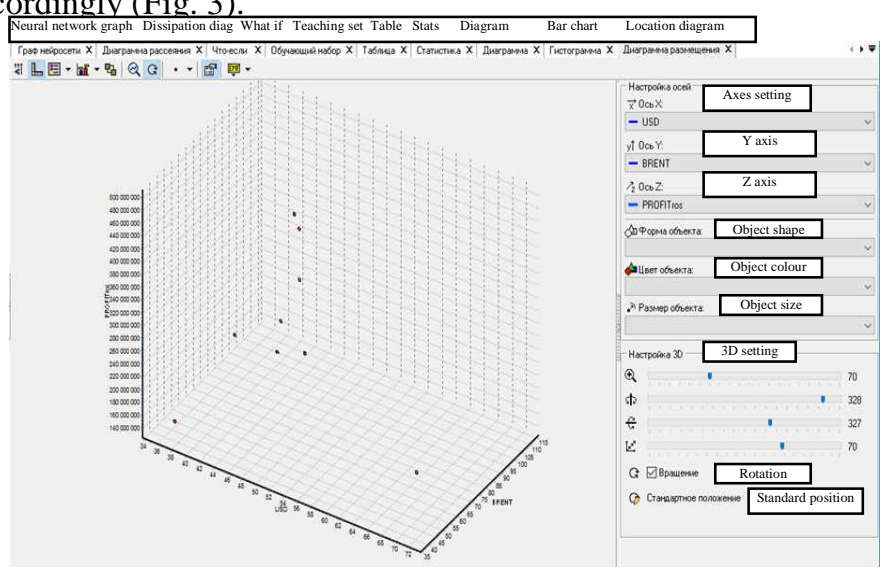

Fig. 3. Data visualization in the 3D diagram Source: Author's development
Using Deductor's 'What-if' function, let us add input values as of the end of 2016 and November 2017 to obtain Rosneft's net profit forecast values (Fig. 5).

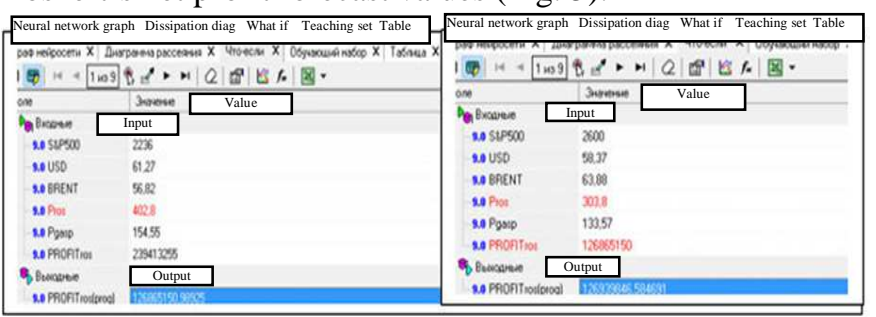
2017

Fig. 4. Roneft's net profit forecast values for 2016 and

Source: Author's development

Thus, Rosneft's net profit forecast values for 2016 and 2017 have been obtained successfully.

\section{RESULTS AND DISCUSSION}

The calculated corporate net profit forecast values are characterized by a high level of accuracy with a margine of error under $5 \%$ (Fig. 6).

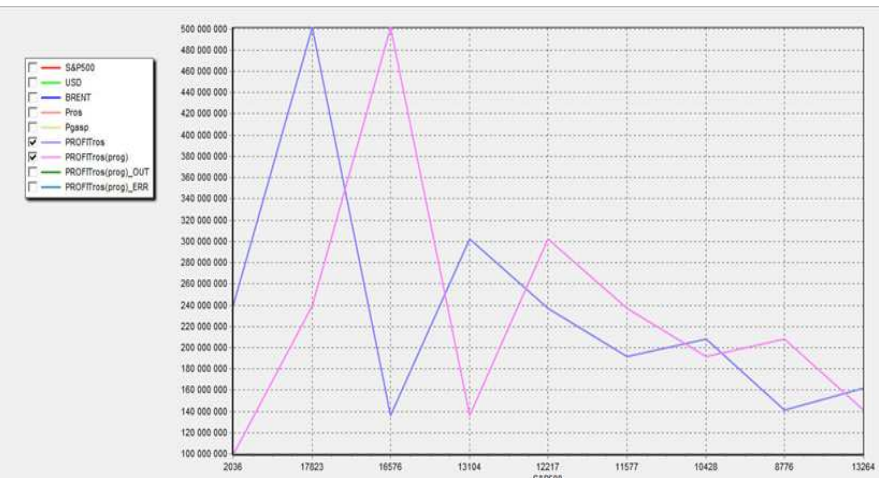

Fig. 5. Actual data vs. neural network forecast Source: Author's development

As we can see, the forecast values practically coincide with or are very close to the actual data. For comparison, let us add the obtained values to Table 2 .

TABLE 2. ACTUAL AND FORECAST VALUES

\begin{tabular}{|c|c|c|c|c|c|c|c|}
\hline \multirow{2}{*}{ Year } & \multicolumn{7}{|c|}{ Parameters } \\
\cline { 2 - 8 } & $\begin{array}{c}\text { S\&P } \\
\mathbf{5 0 0}\end{array}$ & $\begin{array}{c}\boldsymbol{U} \boldsymbol{D} \\
\boldsymbol{D}\end{array}$ & $\begin{array}{c}\boldsymbol{B} \boldsymbol{B} \\
\boldsymbol{e n t}\end{array}$ & Pros & $\begin{array}{c}\boldsymbol{P} \\
\text { gasp }\end{array}$ & Profit ros & $\begin{array}{c}\text { Profit ros } \\
\text { prognos }\end{array}$ \\
\hline \multirow{2}{*}{2017} & 2600 & 58, & 63, & 30,8 & 133,57 & 1268651 & 1269398 \\
& 37 & 88 & & & 50 & 46 \\
\hline \multirow{2}{*}{2016} & 2236 & 61. & 56. & 402.8 & 154.55 & 9923621 & $\begin{array}{c}1268651 \\
50\end{array}$ \\
& & 27 & 82 & & & 4 & 50 \\
\hline \multirow{2}{*}{2015} & 2036 & 72. & 37. & 253.25 & 136.09 & 2394132 & 9923621 \\
& 64 & 28 & & & 55 & 4 \\
\hline \multirow{2}{*}{2014} & 1782 & 50. & 57. & 195.8 & 130.31 & 5013242 & 2394132 \\
& 3 & 95 & 33 & & & 90 & 55 \\
\hline
\end{tabular}

The source:

Source: Author's development 
These calculations show that Rosneft's 2017 net profit forecast value amounted to 126939846 thousand rubles, whereas its actual profit was 126865150 thousand rubles, i.e. $0.0589 \%$ higher.

The neural network made use of some relevant settings which influence the outcome of the formed AI system in certain ways. The sigmoid AI neuron activation type was used in the suggested perceptron (Fig. 7).

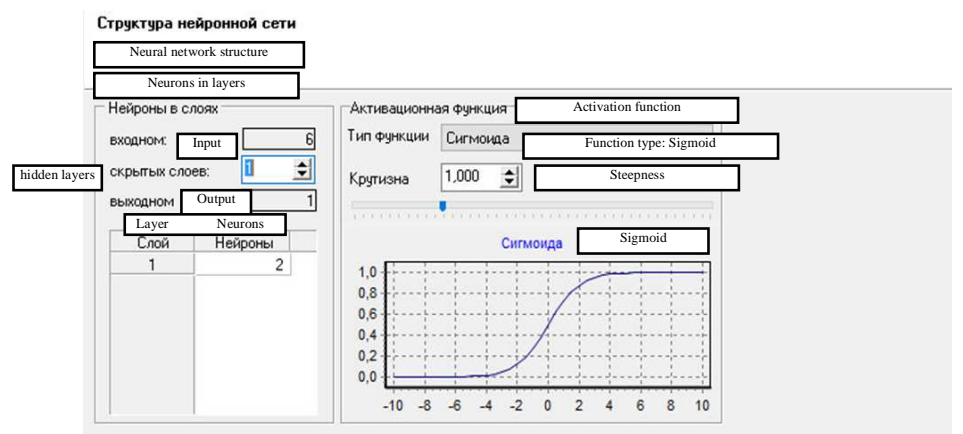

Fig. 6. Neural network activation signal

Source: Author's development

The study described in this article has shown that the obtained Rosneft's profit forecast values are close to the actual values.

\section{A. Rosneft's profit forecasting results}

- Rosneft's 2017 profit forecast value was 126939846 thousand rubles, whereas the actual value reached 126865150 thousand rubles, which is $0.0589 \%$ higher.

- The results of the conducted research show that the average error level does not exceed $5 \%$.

- The hypothesis that it is possible to generate Rosneft's corporate profit forecast for the next year with a $5 \%$ accuracy level has been confirmed.

\section{CONCLUSION}

Thus, summing up the foregoing, the term 'sustainable corporate development' is to be understood, in our opinion, as a steady balanced state of economic resources, which ensures stable profitability and conditions for sustainable development in the long-term period, taking into consideration the most important external and internal factors based on the use of artificial intelligence.

The AI system is an innovative tool which ensures a highly accurate forecast of financial performance of a business entity, notwithstanding the conditions of market uncertainty, which, undoubtedly, allows us to conclude that dynamic and sustainable corporate development is impossible without the use of artificial intelligence systems and big data processing (BigDate).

Forming the innovation vector for the sustainable development of regions based on $\mathrm{AI}$ and big data processing (BigData) plays a key role in achieving profitability of companies as elements of the regional system.

\section{References}

[1] Theory and Methodology of the Financial Management of the Regional Supporting University / S.P. Sazonov, E.E. Kharlamova, I.A. Ezangina, N. Gorshkova, M.A. Kovazhenkov, E.A. Polyanskaya // Journal of Advanced Research in Law and Economics. - 2017. - Vol. 8, No. 1. - pp. 211-219.

[2] S.P. Sazonov, E.E. Kharlamova, N.V. Gorshkova, E.A. Polyanskaya Competitive advantages of the regional support university and its role in the regional development strategy. Science and Society. - 2016. - № 3 (v1). - pp. 180-189.

[3] Lomakin N.I., Loginova E.V. Risk management of the CEA financial system based on fuzzy algorithms and ariticial inelligence systems. In: Management of strategic potential of Russian regions: methodology, theory an practice. Collection of papers at the All-Russian Research Conference. Ed.: A.V. Kopylov. pp. 196-197.

[4] Ekova V.A., Maksimova O.N., Lomakin N.I. Improving instruments of regional sustainable development. Russian entrepreneurship. 2016. Vol. 17. No. 23. pp. 3347-3364.

[5] Vasilyev V.A., Letchikov A.F., Lyalin V.E. Mathematical models for business unit risk evaluation and management. Auditing and Financial Analysis. 2006. No. 4. pp.200-237.

[6] Felmer G.. Sheed A. Iintroduction into stochastic fiinance. Disrete time. / Translated from English. - Moscow, 2008. 496 pages.

[7] Kabanov V.A., Medvedeva L.N., Melikhov V.V., Sazonov S.P., Shakhovskaya L.S., Lomakin N.I., Timoshenko M.A., Aleksandrov A.V., Popova Ya.A., Plotnikov V.A. The artificial intelligence system for forecasting the Green City budget. Software registration certificate RUS 2017663127 03.10.2017

[8] Lomakin N.I., Gogoshidze T.D., Trofimova T.P., Kim V.R., Nguen T.Z., Moskovtsev A.F., Kopylov A.F., Samorodova I.A., Sazonov S.P., Vorotilova O.A. Smart modelling of investment potentil evalutaion of regions based on data quantization. Nauka Krasnoyarya. 2017. Vol. 6, No. 1-3, pp. 44-47.

[9] Lomakin N.I., Dontsova K.S., Chebotareva Yu.A. Neural network model of urban budget imcomes. In: Contemporary socioecomonic system plolicy. Proceddings of the first Russian reseacrh student conference. Volgograd branch of NOU VPO Instituute of Management. 2015. pp. $125-128$.

[10] Comparison of shares of Rosneft URL: http://stocks.investfunds.ru/compare/ 